\title{
Ishlah dalam Pandangan Ibn Asyur dan Signifikansinya dalam Upaya Deradikalisasi (Telaah Penafsiran Q.S al-Hujurat: 9 dalam Kitab Al-Tahrir wa Al-Tanwir)
}

\section{Oleh: Alif Jabal Kurdi}

Email: alifjabalkurdi@gmail.com

Pon Pes LSQ Ar-Rohmah, Yogyakarta

\begin{abstract}
Abstrak
Permasalahan radikalisme masih menjadi trending topic yang menghiasi wajah keberagaman umat Islam. Kesalahpahaman dalam memaknai ayat-ayat Alquran masih menjadi permasalahan utama yang melahirkan pemahaman yang radikal (radikalisme) dan tindakan yang destruktif (terorisme). Maka penting untuk menggali lebih dalam nilai-nilai perdamaian dalam Alqurandengan mengeksplor ayat-ayat yang mencerminkan jati diri ajaran Islam sebagai din al-salam. Q.S al-Hujurat[49]: 9 merupakan salah satu representasi ayat Alquran yang menegaskan bahwa Islam adalah agama yang solutif bukan provokatif. Melaui penafsiran salah satu cendekiawan muslim kontemporer yang masyhur dengan teori maqashidnya, Ibn 'Asyur, penulis akan berusaha menemukan cara pandang baru dalam membaca ishlah dari kacamata tafsir maqashidi. Selain itu, tulisan ini juga diproyeksikan untuk melihat konsistensi teori maqashid Ibn 'Asyur dalam tafsirnya serta mengambil intisari metodologis dan konten penafsirannya sebagai
\end{abstract}


perwujudan bagi upaya menghadirkan penjelasan Islam yang rahmah dan menanggulangi radikalisme.

Kata Kunci: Ishlah, Ibn 'Asyur, Maqashid al-Syariah, Deradikalisasi

\section{Pendahuluan}

Di Indonesia, sejak awal abad ke-21 hingga sekarang, terjadi rangkaian aksi-aksi terorisme yang berdampak signifikan bagi tatanan kehidupan negara. Tragedi bom Bali I di tahun 2002; serangan bom di Hotel J.W Marriot pada tahun 2003; bom Kedubes Australia pada tahun 2004; tragedy bom Bali II pada tahun 2005; serta serangan simultan bom yang kembali mengguncang Hotel J.W Marriot serta Hotel Ritz-Carlton pada tahun 2009; Serangan bom buku dan bom Serpong pada tahun 2011; penembakan polisi di Solo pada tahun 2012; aksi bom bunuh diri dan serangan bersenjata di Thamrin, Jakarta pada tahun $2016 .{ }^{1}$

Serangkaian aksi terorisme yang menimpa Indonesia, ternyata juga melanda berbagai negara di belahan dunia. Di penghujung tahun 2016, beberapa negara seperti Turki, Mesir, Ethiopia, Yaman dan terkahir Jerman menjadi sasarannya. Korbannya tidak tanggung-tanggung, semua kalangan bahkan anak-anak kecil dan perempuan tak berdosa menjadi korbannya. ${ }^{2}$ Dalam pandangan buya Syafi'I Ma'arif, para pelaku teror atau dikenal dengan kelompok ekstrimis-teroris itu adalah penganut teologi maut yang tidak memiliki visi tentang kehidupan. ${ }^{3}$

Para peneliti terorisme dan radikalisme mengatakan bahwa adanya serangkaian tragedi-tragedi di seluruh dunia, tidak bisa dilepaskan dari adanya keberpihakan jaringan terorisme transnasional di baliknya. Setelah memudarnya pengaruh al-Qaeda sebab pemimpin sentral

1 Ansyaad Mbai, Dinamika Baru Jejaring Teror di Indonesia, (Jakarta: AS Production Indonesia, 2014), hlm. 8. Lihat juga Azyumardi Azra dkk, Reformulasi Ajaran Islam: Jihad, Khilafah dan Terorisme, (Bandung: Mizan,2017), hlm.17.

2 Azyumardi Azra dkk, Reformulasi Ajaran Islam: Jihad, Khilafah dan Terorisme, (Bandung: Mizan,2017), hlm.19.

3 Azyumardi Azra dkk, Reformulasi Ajaran Islam: Jihad, Khilafah dan Terorisme, hlm.19. 
mereka-Osama ibn Laden berhasil dilumpuhkan. Kini mereka hadir dengan platform baru dengan membangun wilayah kekuasaan sendiri yang mereka klaim sebagai negara Islam dengan Abu Bakar al-Bahgdadi sebagai khalifahnya. Jaringan ini dikenal dengan nama ISIS (The Islamic State of Iraq and Syiria). Dalam laporan the Soufan Group-sebuah lembaga riset dan kajian strategi Internasional yang bermarkas di New York-ada sekitar 500 hingga 700 orang Indonesia dari total 31.000 orang yang berasal 86 negara yang turut serta menjadi pejuang khilafah ISIS. ${ }^{4}$

Harus diakui bahwa terorisme dilatarbelakangi oleh banyak faktor. Tetapi faktor yang paling dominan adalah faktor ideologi, ${ }^{5}$ dimana aspek paham keagamaan menjadi faktor yang paling determinan. Kesalahpahaman dalam menemukan nilai-nilai universal di balik ayat Alquranmenjadi pemicu para terorisme melakukan aksinya. Pemahaman yang salah ini akibat pendekatan dalam memahami Alquran yang terlalu tekstual—dalam Bahasa al-Jabiri disebut bayani. ${ }^{6}$ Walhasil, Islam yang sejatinya adalah agama yang damai, seolah mengalami distorsi makna dan cenderung diperlihatkan sebagai agama yang gemar memulai konflik dan peperangan.

Melihat realita yang menunjukkan bahwa ideologi adalah faktor paling dominan dari kemunculan kaum radikalis dan ekstrimis. Sehingga menyebabkan adanya kesalahan yang sangat fatal dalam menangkap al-mabadi' al-asasi dalam Alquran. Maka dalam makalah ini penulis akan berupaya mengurai argumentasi penafsiran Ibn 'Asyur dalam menjelasakan Q.S al-Hujurat: 9, yang dianalisis dengan pendekatan maqashid al-syariah yang juga diusung oleh Ibn 'Asyur. Dari hasil analisa tersebut, penulis akan mengambil signifikansi dari

4 Azyumardi Azra dkk, Reformulasi Ajaran Islam: Jihad, Khilafah dan Terorisme, hlm. 20.

5 Dalam teorinya the staircase to terrorism, Fathalli Moghaddam mengatakan bahwa indoktrinasi atau dalam bahasanya disebut moral-engagement adalah fakor utama keberhasilan kelompok terorisme dalam merekrut anggota. Lihat: Fathalli Moghaddam, "The Staircase to Terrorisme", dalam American Psychologist, 2005, hlm. 165.

6 Azyumardi Azra dkk, Reformulasi Ajaran Islam: Jihad, Khilafah dan Terorisme, hlm.90. lihat juga Muhammad Abid al-Jabiri, Bunyah al-Aql al-Arabi, (Beirut: Markaz al-Tsaqafi al-Arabi, 1993), hlm. 20. 
metode dan hasil penafsiran Ibn 'Asyur sebagai model penafsiran yang mampu menjadi basis dalam upaya mewujudkan ishlah di tengah manusia.

\section{Sekilas Tentang Biografi Ibn 'Asyur}

Ibn «Asyur memiliki nama lengkap Muhammad al-Thahir bin Muhammad bin Muhammad Thahir bin Muhammad bin Muhammad Shadzaliy bin Abdul Qodir Muhammad bin «Asyur. Ia lahir pada tahun 1296 H/ 1879 M di desa Marsi yaitu sebuah daerah di Tunisia bagian utara. Ia berasal dari keluarga terhormat yang berasal dari Andalusia. Ayahnya yang bernama Muhammad merupakan seseorang yang dipercaya memegang jabatan penting sebagai ketua Majlis Persatuan Wakaf. Ia menikah dengan Fatimah, anak perempuan dari Perdana Menteri Muhammad bin Aziz al-Bu'atur dan dari pasangan inilah kemudian lahir Muhammad Thahir Ibnu Asyur. ${ }^{7}$

Sejak umur enam tahun Ibnu Asyur mulai diperkenalkan mempelajari al-Qur`an, baik hafalan, tajwid, maupun qiràt-nya di sekitar tempat tinggalnya. Selain itu ia juga mempelajari dan menghafal Matan al-Jurumiyyah juga mempelajari bahasa Perancis kepada al-Sayid Ahmad bin Wannas al-Mahmudiy. Ketika menginjak usia 14 tahun tepatnya pada tahun 1310 H/ 1893 M, Ibnu Asyur mulai menapakkan langkahnya untuk menimba ilmu di Universitas alZaitunah. Zaituniyah adalah sebuah masjid yang dalam perjalanan sejarah menjadi pusat kegiatan keagamaan yang berafiliasi kepada mazhab Maliki dan hanya sebagian yang menganut mazhab Hanafi. Masjid ini juga merupakan lembaga pendidikan yang setaraf dengan alAzhar yang selama berabad-abad berfungsi sebagai pusat pendidikan, informasi dan penyebaran ilmu pengetahuan.

Di universitas itu ia mempelajari fiqh dan ushul al-fiqh, juga bahasa Arab, hadits, tarikh, dan lainnya. Setelah menimba ilmu selama tujuh tahun di Universitas al-Zaitunah, Ibnu Asyur berhasil

7 Ibn 'Asyur, Kasyfal-Mughtiy min al-Ma'aniy wa al-Alfaz al-Waqiah fi al-Muwatha', (Kairo: Dar al-Salam, 2006), h. 7. 
lulus dengan gelar sarjana pada 4 Rabiul Awwal tahun 1317 H/ 11 Juli 1899 M. Ilmu-ilmu yang ia peroleh dari universitas al-Zaitunah dan aktifitas keilmuannya membentuk kepribadian dan intelektualitasnya yang tinggi. Di samping itu perhatian ayah dan kakeknya juga sangat berpengaruh dalam membentuk akhlak yang dimiliki Ibnu Asyur sehingga menjadi ulama besar yang bersahaja di Tunisia. Ibnu Asyur wafat pada hari Ahad bulan Rajab tahun 1393 H/1973 M dan dimakamkan di pemakaman al-Zalaj. ${ }^{8}$

\section{Prinsip Universal Maqashid al-Syari'ah Ibn Asyur}

Dalam upayanya menetapkan maqashid al-Quran, Ibnu 'Asyur berpijak diatas prinsip-prinsip maqashid al-syariah yang telah ia susun dalam Kitabnya Maqashid Al-Syariah Al-Islamiyyah. Selanjutnya Ibnu 'Asyur mengkaji lebih detail dan komprehensif dalam menetapkan maqashid al-Quran atas dasar prinsip-prinsip berikut ini:

1) Al-Fitrah, artinya bahwa ajaran Islam atau syariat Islam yang diturunkan oleh Allah swt untuk kemaslahatan semua manusia sesungguhnya sangat sesuai dengan karakter dasar manusia itu sendiri. Begitu juga, dalam pandangan Imam Ibnuu 'Asyur, fitrah adalah sifat dasar manusia (al-khilqah) dalam artian sebuah sistem tertentu (al-nidzham) yang telah Allah tanamkan atau ciptakan pada setiap ciptaannya, baik bersifat lahiriah (yang terlihat) maupun batiniah (tidak terlihat). Ibnu 'Asyur mendasari pandagannya dengan firman Allah dalam surat al-Rum: 30. Ibnu 'Asyur juga membagi fitrah menjadi dua macam: pertama, fithrah 'aqliyyah' yang mengarahkan manusia untuk bisa merasakan adanya Allah yang menguasai alam semesta ini. Dengan fitrah 'aqliyyah ini manusia menyadari perlu dan pentingnya syariat untuk mengatur kehidupan manusia itu sendiri. Kedua, fitrah nafsiyyah 'adalah naluri dan keinginan yang diciptakan Allah

8 Ibn 'Asyur, Kasyfal-Mughtiy min al-Ma'aniy wa al-Alfaz al-Waqiah fi al-Muwatha', (Kairo: Dar al-Salam, 2006), h. 12. 
swt pada manusia untuk memenuhi keinginan-keinginan secara baik dan terarah. Contohnya adalah naluri atau fitrah ingin menikah, berinteraksi sosial, membangun peradaban dan sebagainya. ${ }^{9}$

2) Al-Samahah (toleransi/ saling menghormati). Dengan sifat ini seseorang dapat memposisikan segala sesuatu seimbang antara sikap melebihi batas (al-ifrath) dan terlalu menggampangkan sesuatu (al-tasahul). Sikap toleransi ini menurut perspektif Ibnu 'Asyur adalah sebagai pendorong tegaknya keutamaan makna fitrah yang sudah disebutkan sebelumnya. Sifat toleransi ini juga merupakan salah satu sifat yang sangat sesuai dengan fitrah sebagai ciri dasar dari Islam itu sendiri. Lebih dari itu, toleransi merupakan karakter mendasar dari umat ini. Toleransi merupakan bagian penting dari tempat tumbuhnya sifat-sifat mulia lainnya yang diantaranya sikap adil dan sikap proposional dalam bersikap. ${ }^{10}$

3) Al-Musawah (egaliter). Agama Islam adalah agama yang memandang semua manusia di hadapan hukum-hukum syar'iy diberlakukan sama. Aspek ini menjadikan perhatian tersendiri bagi Imam Ibnuu 'Asyur dalam kajian ilmu maqashid syariah sebagai dasar berpikir filosofis filsafat hukum Islam itu sendiri. Persamaan (al-musawah) ini penting dalam penerapannya terutama terhadap lima prinsip dasar yang menjadi tujuan syariat Islam: hifdzh al-din, al-nafs, al-'aql, al-nasl dan al-mal. Prinsip egaliter ini, menurut Ibnu 'Asyur tidak dipengaruhi oleh orang yang kuat atau lemah, kerabat atau bukan, semua status sama di dalam pandangan Islam. ${ }^{11}$

4) Al-Hurriyah (kebebasan). Sesungguhnya al-hurriyah merupakan turunan atau bagian dari al-fitrah itu sendiri.

9 Ismail al-Hasaniy, Nadzariyyah al-Maqashid 'inda al-Imam Muhammad al-Thahir bin "Asyur, (Virginia: al-Ma’had al-Ilmiy lil Fikr al-Islamiy, 1995 M/ 1426 H), h. 263-273.

10 Ibn 'Asyur, Maqashid al-Syariah al-Islamiyah, (Yordan: Dar Nafais, 2001M), h. 117-119.

11 Ibn 'Asyur, Maqashid al-Syariah al-Islamiyah, h. 119. 
Menurut Ibnu 'Asyur, ketika seseorang diberlakukan sama secara hukum dari segala bentuk perbuatannya (al-tasharuf), maka disitulah ditemukan sifat al-hurriyah (kemerdekaan). ${ }^{12}$

\section{Penafsiran Q.S al-Hujurat: 9}

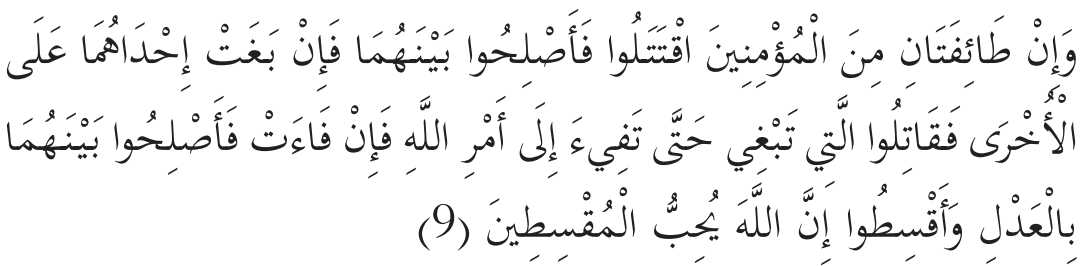

Artinya: "Dan kalau ada dua golongan dari mereka yang beriman itu berperang hendaklah kamu damaikan antara keduanya! tapi kalau yang satu melanggar perjanjian terhadap yang lain, hendaklah yang melanggar perjanjian itu kamu perangi sampai surut kembali pada perintah allah. kalau dia telah surut, damaikanlah antara keduanya menurut keadilan, dan hendaklah kamu berlaku adil; sesungguhnya allah mencintai orangorang yang berlaku adil."

Di awal penafsiran ayat ini, Ibn Asyur mengutip Q.S al-Hujurat:6 $\{$ \{ أنْ تُصيبوا قَوْهًا بِجَهَالَة antara dua kelompok umat muslim—dalam konteks Indonesia dapat direfleksikan dengan perselisihan antara dua kelompok umat muslim yang berbeda afiliasi dalam hal ideologi ataupun organisasi masyarakat (ormas)—disebabkan oleh jahalah yang dapat berupa berita bohong (hoax), berita yang sifatnya mengadu domba dan merendahkan satu kelompok dengan kelompok lainnya (hate speech). Dampak yang ditimbulkan dari adanya perselisihan antar kelompok tentunya lebih besar daripada perselisihan yang terjadi antar individu. Oleh sebab itu terkadang upaya tabyin atau tabayyun sebagai usaha preventif untuk mencegah terjadinya perselisihan itu tidak berhasil. Akhirnya usaha tabyin baru disadari pentingnya saat api fitnah sudah berkobar dan penyesalan tidak lagi berguna. ${ }^{13}$

12 Ibn 'Asyur, Maqashid al-Syariah al-Islamiyah, h. 120.

13 Ibn 'Asyur, al-Tahrir wa al-Tanwir, Juz 26, (Tunis: Dar al-Tunis li al-nasyr, T.T), h. 238-244. 
Dalam menjelaskan asbab al-nuzul ayat ini, Ibn Asyur mengutip beberapa riwayat yang sebagian besar menceritakan tentang kisah perselisihan yang terjadi antara kaum Aus dan Khazraj saat harihari pertama Nabi Muhammad berada di Madinah dan kemudian Nabi Muhammad datang sebagai pihak yang mendamaikan (agent of peace). Setelah itu Ibn Asyur memberikan komentarnya secara umum mengenai riwayat yang dikutipnya dengan mengatakan bahwa dalam ayat ini berlaku status hukman 'aman nazala fi sabab al-khas. Maksudnya meskipun peristiwa yang mengiringi ayat ini sifatnya sebuah kisah yang spesifik akan tetapi kandungan hukum (ibrah) dalam ayat ini tidaklah berlaku hanya pada saat peristiwa itu terjadi saja, namun sifatnya umum. Jadi sikap ishlah Nabi Muhammad dalam menginisiasi rekonsiliasi konflik yang terjadi antara kaum Aus dan Khazraj haruslah diaktualisasikan dalam setiap konflik lainnya yang terjadi. $^{14}$

Penjelasan kebahasaan menjadi salah satu ciri khas dari penafsiran Ibn Asyur. Pada ayat ini, ia mengurai harfu syarth $\left\{\begin{array}{l}\text { lo } \\ \text { \} }\end{array}\right.$ dengan fi'il

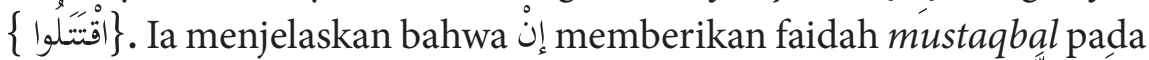

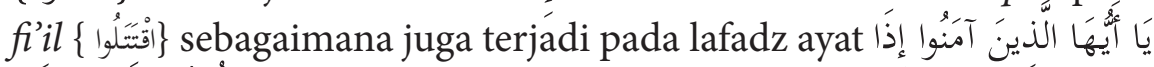

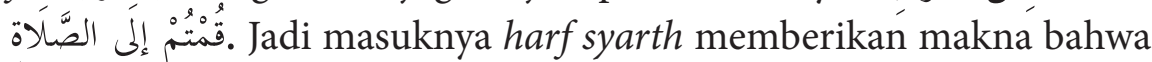
kejadian yang direkam Alqurandengan shigot madhi memiliki potensi akan terjadi di masa-masa selanjutnya. Maka dapat dimaknai bahwa perselisihan ataupun konflik akan senantiasa menghantui kehidupan manusia, maka perintah ishlah tidaklah hanya diaktualisasikan saat konflik terjadi, melainkan harus sudah dilanggengkan dalam kehidupan agar konflik tidak sampai terjadi. ${ }^{15}$

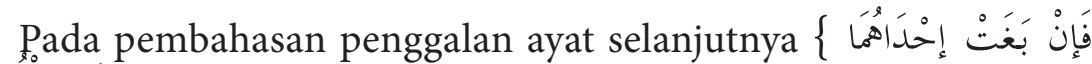
عَلَى الأخْرَى yang memulai perselisihan atau konflik kembali setelah terlaksananya rekonsiliasi, maka kelompok itu (al-thaifah al-baghiyah) haruslah diperangi (diluruskan kembali). Dalam pembahasan ini hal yang

14 Ibn 'Asyur, al-Tahrir wa al-Tanwir, Juz 26, h. 238-244.

15 Ibn 'Asyur, al-Tahrir wa al-Tanwir, Juz 26, h. 238-244. 
menarik adalah mengenai penjelasan Ibn Asyur terhadap kata albaghy. Ibn Asyur memaknai kata al-baghy dengan al-dzulm wa al-i'tida' 'ala haq al-ghair (tindak kedzaliman dan agresi atas hak orang lain). Definisi itu ia ambil dari makna lughawy bukan makna fiqhy dari kata al-baghy ${ }^{16}$. Kemudian dalam penggalan ayat selanjutnya $\{$ التّني تَبْنِين dijelaskan bahwa yang dimaksud di sana adalah kelompok dzalim yáng telah keluar dari kebenaran sehingga wajib diperangi, sebab jika tidak, maka akan memiliki potensi untuk merusak hak-hak dari kelompok yang didzalimi. ${ }^{17}$

Penafsiran selanjutnya pada penggalan ayat $\{$ فَقَاتُلُوا التَّت تَبْغ Asyur menegaskan kembali kewajiban memerangi ${ }^{18}$ al-thaifah albhagiyah. Selain demi menjaga hak-hak orang lain, tindakan itu diambil sebagai langkah solutif, sebab membiarkannya tetap ada berarti menginginkan praktik kedzaliman terus berlangsung. Maka karena yang diperangi adalah sebuah thaifah bukan individu, maka sudah sepantasnya pemerintah turut serta dalam upaya menanggulanginya. Namun yang perlu diperhatikan bahwa upaya penanggulangan dengan memerangi ini bertujuan agar kelompok itu kembali pada jalan Islam yang adil dan menghindari tindak kedzaliman. Dalam konteks kekinian, kelompok ini bisa saja disebut sebagai kelompok Islam radikal yang sejatinya memang harus dikembalikan ideologinya agar bersesuaian dengan ajaran Islam yang mengedepankan rahmat daripada laknat. ${ }^{19}$

Penggalan ayat $\{$ فَإِنْ فَاءتْ فَأَصْلُحوا بَيْنَهُمَا بالْعَدْلَ mengisyaratkan keadaan dimana pósisinya telah berhasil melakukan upaya penanggulangan. Maka tatkala kelompok al-baghiyah itu telah kembali kepada jalan yang benar, selanjutnya upaya rekonsiliasi haruslah

16 Menjelaskan makna fiqhy dari al-baghy

17 Ibn 'Asyur, al-Tahrir wa al-Tanwir, Juz 26, h. 238-244.

18 Dalam pandangan penulis, lafadz bÇÊá yang memiliki faidah musyarakah (respon) tidaklah harus dimaknai sebagai bentuk perlawanan balik yang berupa perang senjata. Karena harus ada unsur equivalent antara yang menyerang dengan penyerang balik. Maka bisa saja bentuk perlawanan balik berupa soft attack (perang pemikiran) maupun hard attack (perang senjata).

19 Ibn 'Asyur, al-Tahrir wa al-Tanwir, Juz 26, h. 238-244. 
dilakukan kembali dengan penuh keadilan. Karena kalimat بالْعَدْل di sana berkedudukan sebagai hal, yang mengindikasikan keharúsan untuk menghadirkan kondisi adil dalam upaya rekonsiliasi. Kemudian

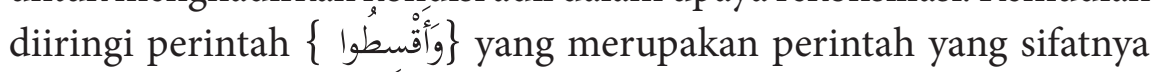
'am dan merupakan buntut dari perkara adil yang dikhususkan dalam konteks ishlah antara dua kelompok yang berselisih. Maksudnya, perintah qisth adalah perintah yang mewajibkan transformasi nilainilai keadilan dalam setiap lini kehidupan dalam upaya rekonsiliasi dengan berdasarkan rasa cinta terhadap kedua belah kelompok agar perselisihan tidak kembali terulang. Sesungguhnya Tuhan mencintai

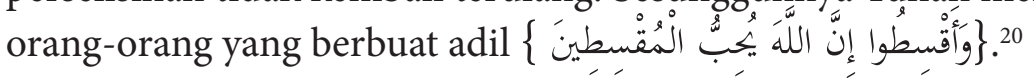

Dari penafsiran Ibn 'Asyur tersebut, dapat ditarik beberapa poin pembahasan penting mengenai paradigma rekonsiliasinya:

1. Tabyin Sebagai Langkah Preventif

Di awal penafsirannya, Ibn Asyur menggunakan metode riwayah dan mengutip Q.S al-Hujurat: 6. Dari metodenya itu, dapat diketahui bahwa Ibn Asyur ingin memberikan penjelasan mengenai faktor-faktor yang dapat menjadi pemicu bagi munculnya konflik — terutama dalam tubuh umat Islam sendiri. Dari sana Ibn Asyur juga mengisyaratkan pentingnya tabyin atau tabayun sebagai langkah preventif terhadap lahirnya konflik akibat dari adanya hoax dan hate speech.

2. Ishlah: Amr Wajib Qabla Wa Ba'da Iqtital

Pada penjelasan aspek asbab al-nuzul dan lughah didapati pernyataan kesimpulan Ibn Asyur yang menyatakan bahwa ishlah bukanlah perkara yang hanya ada di masa Nabi Muhammad. Karena ayat itu dikatakan termasuk dalam kategori ayat dengan muatan hukmun 'am fi sabab al-khas. Serta faidah istiqbal dalam fi'il madhi karena masuknya harf syarth $\left\{\begin{array}{l}\mathrm{i} \\ \}\end{array}\right.$ yang mengindikasikan bahwa konflik akan selalu

20 Ibn 'Asyur, al-Tahrir wa al-Tanwir, Juz 26, h. 238-244. 
menghantui manusia. Sehingga sikap ishlah tidaklah hanya wajib diaktualisasikan saat konflik sudah berkobar namun semestinya telah ditranformasikan dalam kehidupan agar terjadinya konflik dapat diredam.

3. Pentingnya Penegakan HAM

Ibn Asyur menekankan bahwa jika yang dihadapi adalah sebuah thaifah bukan individu maka akan susah meredamnya. Sehingga perlu adanya kerjasama dengan pemerintah dalam upaya menyelesaikan permasalahan yang terjadi. Dalam hal ini, Ibn Asyur benar-benar menekankan bahwa upaya-upaya yang dilakukan itu bertujuan untuk menjaga keberlangsungan HAM setiap orang. Sehingga hak masing-masing manusia tidak tercederai oleh tindakan-tindakan manusia yang lain.

4. Adil Sebagai Landasan Membangun Ishlah

Adil merupakan lawan kata dari dzalim, maka terjadinya tindak kedzaliman disebabkan oleh runtuhnya bangunan keadilan. Maka bersikap adil tidaklah hanya dilakukan dalam prosesi pendamaian saja, namun semestinya mampu ditranformasikan dalam seluruh aspek kehidupan. Dengan begitu tindakan-tindakan yang dapat memicu terjadinya konflik dapat diminimalisir.

\section{Analisis Maqhasid al-Syari’ah: Melihat Konsistensi Ibn 'Asyur dalam Penafsirannya}

Sebelum pembahasan mengenai penafsiran Ibn 'Asyur terhadap Q.S al-Hujurat: 9, telah dijelaskan mengenai prinsip universal maqashid al-syariah yang telah ia susun. Ada empat prinsip yang ia masukan sebagai rumusannya yaitu: 1) al-fitrah;2) al-samahah;3) al-musawa; dan 4) al-hurriyah. Berdasarkan prinsip-prinsip tersebut, bagian pembahasan ini akan mengurai konsistensi Ibn 'Asyur dalam menerapkan prinsip maqashid-nya dalam penafsiran. 
Setelah dilakukan analisis deskriptif terhadap penafsiran Ibn 'Asyur terhadap Q.S al-Hujurat: 9, didapati beberapa poin penting dalam penafsirannya-sebagaimana yang telah dipaparkan dalam pembahasan sebelumnya-yakni: 1) tabyin sebagai langkah preventif; 2) ishlah sebagai perkara yang wajib diaktualisasikan oleh umat Islam kapanpun dan di manapun; 3) pentingnya penegakan HAM; 4) adil sebagai landasan membangun islah.

Sebagai upaya dalam membaca konsistensi Ibn 'Asyur dalam penafsirannya, maka akan dilakukan konfirmasi atas prinsip maqashid Ibn 'Asyur dengan poin-poin penting dalam penafsirannya. Pertama, Ibn 'Asyur menempatkan prinsip fitrah dalam konsep universal maqashid-nya. Dalam menafsirkan Q.S al-Hujurat: 9, Ibn 'Asyur menekankan kepada umat Islam untuk senantiasa mengaktualisasikan ishlah dalam kehidupannya. Dalam tulisannya, Nurcholis Madjid membangun argumen bahwa manusia yang memiliki hakikat sebagai khalifah fi al-ard salah satu tanggung jawab yang dibebankan kepada manusia adalah ishlah al-'ard (memperbaiki kehidupan satu sama lain, memelihara dan meningkatkan mutu hidup bersama). ${ }^{21}$ Adapun fitrah Islam sendiri sebagai agama adalah damai dan mengajarkan pemeluknya untuk mentransformasikan nilai-nilai perdamaian dalam kehidupannya. ${ }^{22}$ Maka apa yang telah disampaikan oleh Ibn 'Asyur dalam penafsirannya dapat dikatakan sesuai dengan prinsip yang ia tanam yakni menekankan ishlah sebagai bagian prinsip universal konsep maqashid-nya.

Kedua, prinsip toleransi atau al-samahah merupakan prinsip universal yang tidak hanya dianut oleh Ibn 'Asyur dan dijadikan salah

21 Nurcholis Madjid, Islam, Doktrin dan Peradaban, (Jakarta: Paramadina, 1992), h. 58. Pernyataan yang hampir serupa juga didapati dalam tulisan Imam Taufiq, lihat: Imam Taufiq, AlquranBukan Kitab Teror: Membangun Perdamaian Berbasis Alquran, (Yogyakarta: Bentang Pustaka, 2016), h. 50.

22 "Damai" dalam Alqurandirepresentasikan dengan kata salam, sebuah kata yang memiliki hubungan semantik dengan kata Islam. Kata salam disebutkan dalam Alquransebanyak 157 kali dalam bentuk kata benda (ism) sebanyak 79 kali, kata sifat (na'at) sebanyak 50 kali, dan kata kerja ( $\left.f^{\prime} i l\right)$ sebanyak 28 kali. Seluruh derivasi sintaksis dari kata salam menunjuk makna 'damai". Lihat: Imam Taufiq, AlquranBukan Kitab Teror: Membangun Perdamaian Berbasis Alquran, h.. 4-5. 
satu bagian prinsip maqashid-nya. Para pakar tafsir kontemporer juga telah menjadikan konsep toleransi sebagai al-mabadi al-asasiy dalam paradigma penafsirannya. Salah satu pakar Hermeneutika di Indonesia, Sahiron Syamsuddin dalam aplikasi teorinya_magna cum maghzaterhadap Q.S al-Hajj: 3940-, memperlihatkan sebuah paradigma penafsiran yang inklusif yang tercermin dalam upayanya menangkap pesan damai di balik ayat qital pertama tersebut. ${ }^{23}$ Ibn 'Asyur juga menjelaskan urgensi prinsip samahah dalam upaya meneguhkan fitrah dan juga sebagai bentuk aplikatifnya. ${ }^{24}$ Dalam konteks penafsirannya, Ibn 'Asyur menekankan urgensi adil sebagai basis dalam mewujudkan ishlah, maka ini dapat dikonfirmasi bahwa prinsip toleransi juga telah diterapkan oleh Ibn 'Asyur, salah satu representasi sikap adil adalah adanya sikap toleransi atau inklusif, sebagai cerminan dari konsep ummatan wasathan. ${ }^{25}$

Ketiga, prinsip egaliter yang diusung oleh Ibn 'Asyur menjadi salah satu diskursus yang menarik dari penafsirannya. Dalam menafsirkan Q.S al-Hujurat: 9, Ibn 'Asyur menekankan bahwa demi mewujudkan ishlah, umat Islam haruslah mampu menjamin terlaksananya hak masing-masing orang dan jangan sampai mencederainya. Ibn 'Asyur juga menekankan bahwa di mata hukum, kedudukan setiap orang adalah sama. Dengan begitu pelaksanaan dharuriyah al-khamsah dapat dijalankan secara optimal. ${ }^{26}$

Keempat, prinsip kebebasan (al-hurriyah) yang diusung oleh Ibn 'Asyur bukanlah kebebasan dalam artian bebas melakukan segala hal tanpa batasan. Kebebasan yang dimaksud oleh Ibn 'Asyur adalah kebebasan yang tetap terikat oleh hukum yang berlaku serta berpedoman pada prinsip-prinsip sebelumnya. ${ }^{27}$ Dalam penafsirannya

23 Sahiron Syamsuddin, "Pesan Damai Di Balik Seruan Jihad", dalam Sahiron Syamsuddin (e.d), Islam Tradisi dan Peradaban, (Yogyakarta: Bina Mulia Press, 2012), h. 97.

24 Ibnu 'Asyur, Maqashid al-Syariah al-Islamiyah, h. 117-119.

25 Abdul Mustaqim, "De-radicalization in Qur'anic Exegesis (Re-interpretation of "Violence Verses" Toward Peaceful Islam", dalam Advances in Social Science, Education and Humanities Research (ASSEHR), Vol. 137, 2018, h. 218.

26 Ibnu 'Asyur, Maqashid al-Syariah al-Islamiyah, h. 119.

27 Ibnu 'Asyur, Maqashid al-Syariah al-Islamiyah, h. 120. 
yang memberikan pandangan atas pentingnya tabyin atau tabayyun, dalam pandangan penulis, Ibn 'Asyur seakan mengisyaratkan bahwa dalam ranah komunikasi, kegiatan memperoleh informasi dan menyebarkannya adalah sebuah kebebasan. Namun dalam upaya mewujudkan ishlah dan menghindari iqtital, maka perlu adanya klarifikasi terhadap informasi-informasi yang didapat agar informasi yang kontennya melanggar prinsip-prinsip universal maqashid dapat dipertanggungjawabkan dan perdamaian tetap terjaga.

\section{Signifikansi Pandangan Ibn 'Asyur Sebagai Upaya Deradikalisasi}

Dalam analisisnya, Abdul Mustaqim mengkategorikan radikalisme menjadi dua yakni soft radicalism dan hard radicalism. Dalam penjelasannya, yang dimaksud dengan soft radicalism adalah pemahaman radikal yangf masih berkisar pada level kognitif (ideologi) dan tidak sampai diaktualisasikan dalam bentuk tindakan (terorisme). Namun, pemahaman dalam radikal dalam level ini juga berdampak pada banyaknya klaim-klaim bid'ah dan takfiri (pengafiran) terhadap golongan yang tidak seideologi. Adapun yang dimaksud dengan hard radicalism adalah bentuk ideologi yang radikal yang sampai pada level aktualisasi. Tindakan secara nyata yakni aksi terorisme yang menghancurkan apapun yang tidak sejalan dengan ideologi mereka dan yang mereka klaim sebagai thagut (musuh Allah). ${ }^{28}$

Yusuf Qardhawi juga memberikan pandangannya terkait dengan fenomena radikalisme dan terorisme. Ia menyebutkan bahwa ciri-ciri radikalisme antara lain: fanatik kepada satu pendapat serta menegasikan pendapat orang lain; abai terhadap historisitas Islam; tidak dialogis; dan harfiah dalam memahami teks agama tanpa mempertimbangkan tujuan esensial syariat (maqashid al-syariah). ${ }^{29}$

28 Abdul Mustaqim, "De-radicalization in Qur'anic Exegesis (Re-interpretation of "Violence

Verses" Toward Peaceful Islam", dalam Advances in Social Science, Education and Humanities Research (ASSEHR), Vol. 137, 2018, hlm. 218.

29 Irwan Masduqi, Ber-Islam Secara Toleran, (Bandung: Mizan, 2011), hlm. 117. 
Demi merespon problem ideologi ini, maka meminjam istilah yang digunakan oleh Nasaruddin Umar bahwa "deradikalisasi adalah sebuah keharusan”. Selain sebagai kontra narasi terhadap propagandapropaganda ideologi radikal. Deradikalisasi juga bertujuan untuk meneguhkan kembali bahwa Islam bukanlah agama yang mengajak pada tindakan ekstrim - seperti halnya diklaim oleh islamophobic. ${ }^{30}$

Salah satu bentuk deradikalisasi dalam upaya men-counter paham radikalisme adalah dengan memberikan penafsiran yang sesuai dengan prinsip-prinsip dasar Islam (maqashid al-syariah). Menghadirkan pandangan Ibn 'Asyur dalam memaknai ishlah sebagai salah satu fitrah Islam dan otomatis menjadi fitrah umat muslim adalah salah satu langkah preventif yang dapat diterapkan. Adapun beberapa poin penting dari pandangan Ibn 'Asyur tentang ishlah yang dapat dijadikan pedoman bagi umat Islam agar tidak radikal dalam pikiran maupun tindakan serta terus mengusung spirit nilai-nilai universal Islam dalam menjalani kehidupannya, antara lain:

1) Menerapkan Metode Istiqra' dalam Upaya Memahami Alquran Prinsip-prinsip maqashid Alquran yang dituangkan Ibn 'Asyur dalam kitabnya Maqashid al-Syariah al-Islamiyah, merupakan hasil penelaahannya terhadap Alqurandengan metode istiqra'. Metode istiqra' sendiri adalah melakukan telaah terhadap ayat-ayat Alquran secara holistic dan tidak parsial. Maksudnya tidak hanya memahami ayat berdasarkan makna leksikalnya saja (terjemahan). Dalam kitabnya, al-Burhan fi 'Ulum Alquran, al-Zarkasyi mengatakan bahwa ada beberapa sebab seseorang tidak mampu menggapai makna Alquran, dan salah satunya adalah berpegang pada terjemahan maupun guru yang tidak memiliki kapasitas dalam menafsirkan Alqurankecuali hanya ilmu terjemah ('ilm bi al-dzhahir). Sehingga perlu adanya tadabbur dan tafakkur yang lebih mendalam sehingga

30 Nasaruddin Umar, Deradikalisasi Pemahaman Alqurandan Hadis, (Jakarta: Quanta, 2014), hlm. 5. 
didapati moral value-oleh Fazlur Rahman disebut ideal moral-di dalamnya. ${ }^{31}$

2) Berpegang Pada Prinsip-Prinsip Universal dalam Alquran(Maqashid Alquran)

Dalam menafsirkan Q.S al-Hujurat: 9, Ibn 'Asyur telah konsisten berpegang pada prinsip maqashid Alquran yang disusunnya. Dari penafsirannya atas ayat ishlah tersebut, Ibn 'Asyur telah menunjukkan bahwasanya Islam adalah agama yang sangat mengedepankan perdamaian dan kemanusiaan. Dengan begitu tidak ada alasan bagi umat Islam untuk menyalahi prinsip-prinsip dasar Alquran. Maka tindakantindakan radikal dapat dikatakan telah menyalahi prinsipprinsip Islam yang tertuang dalam Alquranitu sendiri. Dengan berpegang pada prinsip-prinsip universal Alquran, seharusnya tindakan-tindakan radikal tidak terjadi. Justru Islam seharusnya hadir untuk menjadi penengah bukannya provokator. Adapun jika dikaitkan dengan konteks saat ini, peperangan baru boleh dilakukan tatkala umat Islam sudah pada posisi terdesak-sebagaimana konteks Q.S al-Hajj: 3940-dan itupun tidak menjadi upaya offensive melainkan defensive. $^{32}$

Maka sudah semestinya umat Islam tidak mudah terbawa pada tafsir-tafsir yang justru mengarahkan mereka menjadi "pencoreng" nama baik Islam sendiri. Memang tidak bisa dipungkiri dalam Alquranjuga terdapat ayat-ayat yang dapat memicu tindakan radikal apabila disalahpahami. Adapun solusi dalam menyikapi penafsiran-penafsiran terhadap ayat-ayat qita $^{33}$ yang dapat dijadikan alternatif terbaik adalah dengan memposisikan ayat-ayat qital sebagai golongan ayat-ayat

31 Badrudin Muhammad ibn Abdullah al-Zarkasyi, al-Burhan fi 'Ulum Alquran, Jilid 2, (Kairo: Dar al-Turats, 1984), hlm. 180-181.

32 Abdul Mustaqim, "Deradikalisasi Penafsiran Alqurandalam Konteks Ke-Indonesiaan yang Multikultur", dalam Suhuf, Vol. 6, No. 2, 2013, hlm. 149-150.

33 Contoh ayat-ayat qital antara lain: Q.S al-Baqarah 191, Q.S al-Nisa' 89, Q.S al-Anfal 60. 
mutasyabihat. Sehingga pemakanaanya pun harus dikembalikan kepada ayat-ayat muhkamat yakni ayat-ayat yang sejalan dengan prinsip-prinsip universal Islam, seperti halnya Q.S al-Hujurat: 9.34

\section{Kesimpulan}

Muslim radikal dan teroris telah gagal mendapatkan prinsipprinsip universal di balik ayat-ayat Alquran. Kesalahpahaman itu telah menjerumuskan mereka pada tindakan-tindakan yang menyalahi fitrah Islam. Salah satu penyebabnya adalah berpegangnya mereka pada ilmu dzhohir (terjemahan) dalam memahami Alquran. Implikasi dari kesalahan mereka adalah munculnya fenomena islamophobia yang mengatakan bahwa Alquranadalah kitab teror. Maka perlu adanya upaya dalam membenahi kembali kesalahpahaman tersebut.

Ibn 'Asyur seorang mufassir era modern telah memberikan sebuah pedoman dalam memahami Alqurandengan memberikan prinsip-prinsip universal Islam yang terkandung dalam Alquran. Salah satu penafsirannya yang diangkat guna melihat konsistensinya dalam menerapkan pendekatan yang ia bangun adalah penafsiran terhadap Q.S al-Hujurat: 9. Dalam penafsirannya, Ibn 'Asyur terlihat sangat mengedepankan nilai-nilai perdamaian dan kemanusiaan yang merupakan fitrah dari ajaran Islam yang menjunjung kemashlahatan.

Model penafsiran Ibn 'Asyur-baik dari segi metode maupun produk-dapat menjadi salah satu alternatif dalam upaya deradikalisasi. Adapun signifikansi pandangan Ibn 'Asyur dalam upaya deradikalisasi antara lain: 1) menerapkan metode istiqra' dalam upaya memahami Alquran; 2) berpegang pada prinsip-prinsip universal dalam Alquran(maqashid Alquran). Kemudian salah satu alternatif yang dapat dijadikan langkah preventif untuk menghindari kesalahpahaman dalam memahami ayat-ayat qital adalah dengan merujuk pada teori Sahiron Syamsuddin yang menggagagas ulang pemaknaan ayat muhkam dan mutasyabih.

34 Sahiron Syamsuddin, "Pesan Damai Di Balik Seruan Jihad", dalam Sahiron Syamsuddin e.d, Islam Tradisi dan Peradaban, (Yogyakarta: Bina Mulia Press, 2012), hlm. 97. 


\section{DAFTAR PUSTAKA}

'Asyur, Ibn. 2001. Maqashid al-Syariah al-Islamiyah. Yordan: Dar Nafais.

2006. Kasyf al-Mughtiy min al-Ma'aniy wa al-Alfaz alWaqiah fi al-Muwatha'. Kairo: Dar al-Salam.

. T.T. al-Tahrir wa al-Tanwir. Juz 26. Tunis: Dar al-Tunis li al-Nasyr.

Azra, Azyumardi dkk. 2017. Reformulasi Ajaran Islam: Jihad, Khilafah dan Terorisme. Bandung: Mizan.

Hasaniy, Ismail. 1995. Nadzariyyah al-Maqashid 'inda al-Imam Muhammad al-Thahir bin 'Asyur. Virginia: al-Ma'had al-Ilmiy lil Fikr al-Islamiy.

Jabiri, Muhammad Abid. 1993. Bunyah al-Aql al-Arabi. Beirut: Markaz al-Tsaqafi al-'Arabi.

Madjid, Nurcholis. 1992. Islam, Doktrin dan Peradaban. Jakarta: Paramadina.

Masduqi, Irwan. 2011. Ber-Islam Secara Toleran. Bandung: Mizan..

Mbai, Ansyaad. 2014. Dinamika Baru Jejaring Teror di Indonesia. Jakarta: AS Production Indonesia.

Moghaddam, Fathalli. 2005. “The Staircase to Terrorisme”, dalam American Psychologist.

Mustaqim, Abdul. 2013. "Deradikalisasi Penafsiran Alqurandalam Konteks Ke-Indonesiaan yang Multikultur”. dalam Suhuf. Vol. 6. No. 2.

.2018. "De-radicalization in Qur'anic Exegesis (Reinterpretation of "Violence Verses" Toward Peaceful Islam", dalam Advances in Social Science, Education and Humanities Research (ASSEHR). Vol. 137.

Syamsuddin, Sahiron. 2012. "Pesan Damai Di Balik Seruan Jihad", dalam Sahiron Syamsuddin (e.d), Islam Tradisi dan Peradaban. Yogyakarta: Bina Mulia Press. 
Taufiq, Imam. 2016. AlquranBukan Kitab Teror: Membangun Perdamaian Berbasis Alquran. Yogyakarta: Bentang Pustaka.

Umar, Nasaruddin. 2014. Deradikalisasi Pemahaman Alqurandan Hadis. Jakarta: Quanta.

Zarkasyi, Badrudin Muhammad Ibn Abdullah. 1984. al-Burhan fi 'Ulum Alquran. Jilid 2. Kairo: Dar al-Turats. 